8. Маркова, М. В. Функціональність сімейної системи як фактор предикції / превенції розвитку порушень психічного здоров'я у батьків дітей, хворих на онкологічну патологію [Текст] / М. В. Маркова, О. В. Піонтковська // Міжнародний неврологічний журнал. - 2013. - № 4 (58). - С. 49-53.

9. Піонтковська, О. В. Поведінкові патерни подолання стресу у батьків онкохворих дітей [Текст] / О. В. Піонтковська // Журнал психиатрии та медицинской психологии. - 2013. - № 1 (32). - С. 80-83.

10. Кужель, І. Р. Оцінка рівня стресу та вираженості психопато- логічної симптоматики серед членів родини інкурабельних онкологічних хворих [Текст] / І. Р. Кужель // Медична психологія. - 2010. - Т. 5, № 4. - С. 50-59.

11. Піонтковська, О.В.Стан психічного здоров'я батьків дітей з онкологічною патологією [Текст] / О. В. Піонтковська // Український вісник психоневрології. - 2013. - Т. 21, № 1 (74). - С. 90-94.

12. Ветрила, Т. Г. Состояние психического здоровья членов семьи, в которой растет ребенок с нарушением психического развития [Текст] / Т. Г. Ветрила // Архів психіатрії. - 2009. - Т. 15, № 2 (57). - С. 47-51.

13. Завгородня, Н. І. Механізм формування і клінічні особливості розладів адаптації у жінок, що народили недоношену дитину [Текст] / Н. І. Завгородня // Експериментальна і клінічна медицина. - 2014. - № 1 (62). - С. 131-136.

Рекомендовано до публікачії д-р мед. наук, професор Кожина Г. М. Дата надходження рукопису 10.05.2017

Духовський Олександр Ерікович, завідувач відділення, дитяче нейрохірургічне відділення, Харківської міської клінічної лікарні швидкої й невідкладної медичної допомоги ім. проф. А. І. Мещанінова, пров. Балакірєва, 3-а, м. Харків, Україна, 61018

E-mail: alex_duhneiro@me.com

\title{
УДК: 616.89
}

DOI: $10.15587 / 2519-4798.2017 .109173$

\section{РОЗРОБКА МЕТОДОЛОГІЇ АРТ-ТЕРАПІЇ В СИСТЕМІ ТЕРАПІЇ ХВОРИХ НА ШИЗОФРЕНІЮ}

\section{() О. О. Кришталь}

У ході дослідження запропонована двоетапна система арт-терапії в комплексній терапії хворих на шизофренію та доведено їх ефективність. Встановлена виражена позитивна динаміка рівня сочіального функціонування хворих та позитивна динаміка позитивних, негативних $і$ загальних психопатологічних синдромів за шкалою PANSS.

Арт-терапія сприяє швидкій соціальної реінтеграџії хворих на шизофренію, покращення якості їх життя Ключові слова: арт-терапія, хворі на шизофренію, соціальне функціонування, позитивні, негативні, загальні психопатологічні синдроми

\section{1. Вступ}

Шизофренія - одне 3 найбільш поширених психічних розладів, що характеризується поліморфізмом психопатологічних проявів, в основному у сфері мислення, емоцій і волі, а також порушенням єдності психічних процесів і призводить до несприятливих соціальних і економічних наслідків [1].

Хворі на шизофренію займають до 50 \% ліжок психіатричних стаціонарів і дають один 3 найбільш високих відсотків непрацездатності [2].

В даний час в Україні ведеться робота 3 оптимізації функціонування психіатричної служби, метою якої є надання максимально ефективної спеціалізованої допомоги пацієнтам [3]. При цьому підвищення ефективності надання спеціалізованої допомоги проводиться за двома напрямками: впровадження сучасних фармакологічних препаратів 3 підбором оптимальних засобів лікування і впровадження нових форм немедикаментозно орієнтованої допомоги пацієнтам [4, 5].
Арт-терапія є одним із сучасних методів психотерапевтичного впливу, який використовує можливості образотворчого мистецтва в поєднанні з лікувальними факторами, пов'язаними з відносинами пацієнта з фахівцем та групою [6].

\section{2. Обгрунтування дослідження}

Сучасний етап розвитку психіатрії характеризується широким використанням атипових нейролептиків, які досить швидко купірують продуктивну i негативну психопатологічної симптоматики, покращують когнітивний дефіцит і володіють мінімальними побічними ефектами [7]. Надзвичайно важливим фактором також $є$ можливість швидкого відновлення якості життя та соціального функціонування у хворих на шизофренію [8].

Сьогодні арт-терапія набуває все більшої популярності. Методи арт-терапії належать до проективних методик, за допомогою яких здійснюється сублімація в зовнішній світ найбільш тривожних 
аспектів життя. Одна з важливих переваг арт-терапії полягає в тому, що мистецтво дозволяє в прихованій символічній формі реконструювати конфліктну травматичну ситуацію і відшукати їі вирішення. У процесі терапевтичної роботи відбувається м'яке опрацювання та корекція травмуючих подій [9].

Вищевикладене обумовило актуальність і необхідність проведення даного дослідження.

\section{3. Мета дослідження}

Розробка та апробація методології арт-терапії в системі терапії та реабілітації хворих на шизофренію.

\section{4. Матеріал та методи}

Для досягнення поставленої мети, за умови інформованої згоди 3 дотриманням принципів біоетики та деонтології на базі Харківської обласної клінічної психіатричної лікарні № 3 протягом 2012 2016 рр було проведено комплексне обстеження 125 хворих, обох статей (70 жінок та 55 чоловіків), у віці 20-45 років (середній вік $35,0 \pm 2,0$ років) з встановленим діагнозом шизофренія у період стабілізації стану.

Усі пацієнти отримували регламентовану психофармакотерапію згідно Клінічного протоколу надання медичної допомоги хворим на шизофренію MO3 України в межах забезпечення лікувального закладу. Основну групу (пацієнти якої приймали участь у арт-терапії) склали 95 осіб (54 жінки та 41 чоловік), середній вік обстежених $35,0 \pm 2,0$ років. В контрольну групу увійшли 30 хворих (16 жінок та 14 чоловіків), які отримували стандартну регламентовану терапію у лікарні, середній вік обстежених $35,0 \pm 2,0$ років.

У дослідженні були використані наступні методи обстеження: клініко-психопатологічний, який базувався на загальноприйнятих підходах до психіатричного обстеження шляхом інтерв'ювання та спостереження. Опитування здійснювалось із застосуванням діагностично-дослідницьких критеріїв MКX-10 та «Кваліфікаційної шкали оцінки вираженості позитивних, негативних і загальних психопатологічних синдромів» (PANSS).

Соціальне функціонування хворих досліджували за допомогою Шкали інвалідності WHO/DAS (Disability assessment Scale), яка оцінює ступінь загальної поведінкової дисфункції (самообслуговування, інтереси та зайнятість, діяльність в сім'ї та дома, спілкування та ізоляція), виконання індивідуальних соціальних ролей (участь в сімейних справах, сімейна роль, шлюбна роль, статева роль, роль батька, соціальні контакти, професійна роль, зацікавленість та інформованість, поведінка у нестандартних складних ситуаціях), внутрішньолікарняне функціонування (поведінка в палаті, думка медсестер та родичів, заняття пацієнта, контакт 3 зовнішнім світом) та рівень дисфункції модифікуючих чинників (WHO, 1988).

Математико-статистична обробка результатів дослідження проводилась 3 використанням па- кетів спеціалізованого програмного забезпечення (Statistica 6.0, MS Excel) з використанням методики t-критерію Ст'юдента.

\section{5. Результати дослідження}

Для хворих основної групи був розроблений курс арт-терапії, основними цілями якого були:

- зайнятість пацієнтів за рахунок їх залучення в змістовну діяльність;

- розвиток і підтримка їх творчих навичок;

- сенсорна стимуляція;

- відреагування почуттів і переживання позитивних емоцій, пов'язаних з творчою активністю і їі результатами;

- підтримка і розвиток комунікативних навичок, самостійності і самоорганізації;

- психологічна інтеграція пацієнтів.

Арт-терапевтична інтервенція мала довгостроковий характер і складається 3 двох послідовних блоків: основного (інтенсивного) - на стаціонарному етапі лікування і підтримуючого - на амбулаторному (позалікарняному). Стаціонарний етап - 12 занять, тривалістю 45-60 хвилин з частотою 2 рази на тиждень.

Амбулаторний етап - 6 занять, тривалістю 1-1,5 години 3 частотою 1-2 рази на тиждень.

Найбільш ефективним був груповий варіант арт-терапії, у рамках основного блоку арт-терапія здійснювалася в закритих групах, підтримуюча - в частково відкритих під керівництвом лікаря-психіатра/психотерапевта і медичного психолога.

Структура сесій включає три основні етапи: введення (настрій); етап виконання основної роботи 3 теми (творче навантаження), етап обговорення (завершення).

Як показали результати дослідження до основних принципів проведення арт-терапії хворим на шизофренію слід віднести:

- структурований стиль ведення;

- регуляцію інтенсивності емоційних і інформаційних навантажень;

- емоційне заохочення (підкріплення) при досягненні заданого рівня майстерності;

- створення і утримання високого рівня позитивних емоцій;

- дотримання принципів ефективної критики при розборі помилок: доброзичливість, шанобливість;

- утримання високого рівня креативності.

Основним факторами психотерапевтичного впливу в арт-терапії були: фактор художньої експресії, фактор внутрішньогрупових комунікативних процесів і відносин, фактор інтерпретації і вербальної зворотного зв’язку.

Як показали результати дослідження в процесі арт-терапії відзначалася наступна динаміка художньої експресії: створювані на початкових етапах образи характеризувалися аморфністю, розпливчатістю меж, «стіканням форм», орнаментарністю, змішанням різних стилів, а на більш пізніх стадіях 
арт-терапії набували символічний, архетіпний характер, мали структурність і завершеність.

До початку психоосвітнього втручання середній сумарний бал за позитивними шкалами PANSS складав в основній групі - 26,1 4,1 ; у контрольній $26,4 \pm 4,1$ бали; після завершення терапії $-6,7 \pm 1,5$, i $13,1 \pm 1,3$ балів, відповідно. Рівень виразності позитивних симптомів в основній групі знизився на 69,3\%, в контрольній - на 41,1 \%, відповідно.

До початку лікування середній сумарний бал за негативними шкалами PANSS складав в основній

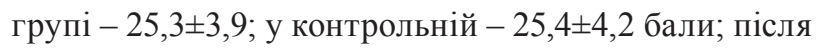
завершення терапії - 7,6 $\pm 1,1$ та 14,2 $\pm 1,6$ балів, відповідно. Рівень виразності негативних симптомів в основній групі знизився на $61,1 \%$, в контрольній - на 49,8 \%, відповідно.

Середній сумарний показник за шкалами загально-психопатологічних порушень до початку лікування складав в основній групі - 52,1土9,1; в контрольній - 52,3 $\pm 9,0$ балів; після завершення терапії$17,7 \pm 2,9$ та $30,1 \pm 6,8$ балів, відповідно. Рівень виразності загально-психопатологічних симптомів в основній групі знизився на $60,8 \%$, у контрольній - на 39,7 \%, відповідно.

Рівень виразності загального балу за шкалою PANSS в основній групі знизився на $65,1 \%$, в контрольній - на 42,9\%.

У ході дослідження встановлено, що на тлі комплексної терапії з використанням арт-терапії суттєво покращився рівень соціального функціонування хворих (табл. 1).

Таблиця 1

Рівень покращення рівня соціального

функціонування обстежених хворих ( \%)

\begin{tabular}{|l|c|c|}
\hline \multicolumn{1}{|c|}{$\begin{array}{c}\text { Рівень соціального } \\
\text { функціонування }\end{array}$} & $\begin{array}{c}\text { Основна } \\
\text { група }\end{array}$ & $\begin{array}{c}\text { Контрольна } \\
\text { група }\end{array}$ \\
\hline Загальна поведінкова дисфункція & 75,3 & 52,1 \\
\hline $\begin{array}{l}\text { Дисфункція при виконанні } \\
\text { соціальних ролей }\end{array}$ & 61,5 & 31,9 \\
\hline $\begin{array}{l}\text { Порушення функціонування } \\
\text { пацієнтів у лікарні }\end{array}$ & 86,4 & 69,4 \\
\hline $\begin{array}{l}\text { Дисфункція модифікуючих } \\
\text { чинників у хворих }\end{array}$ & 91,1 & 59,8 \\
\hline
\end{tabular}

За результатами полуторарічного катамнестичного спостереження в основній групі на тлі проведеної комплексної терапії з використуванням арт-терапії у 77,5 \% хворих було досягнуто стійкого терапевтичного ефекту, який зберігався протягом 2 років, у 15,1\% - стан залишався без динаміки, і у 7,4 \% - відмічався рецидив захворювання. У групі контролю поліпшення стану відмічено у 40,4 \% пацієнтів, у 31,2\% - не спостерігалося позитивна динаміка психічного стану, у 28,4 \% регіструвалась госпіталізація у зв'язку з рецидивом захворювання. Критеріями ефективності були: стійкість ремісії, частота госпіталізації, якість життя, рівень тривоги, поліпшення психічного стану.

Таким чином, як показали результати дослідження, комплексний підхід в терапії шизофренії, який включав в себе психофармакотерапію з використанням атипових нейролептиків у поєднанні 3 арт-терапією, призводить до відновлення соціальної активності і успішної ресоціалізації хворих.

\section{6. Обговорення результатів дослідження}

У ході дослідження встановлена висока результативність арт-терапії в порівнянні 3 традиційним комплексним лікуванням щодо редукції негативної, продуктивної і загальнопсихопатологічної симптоматики у хворих на шизофренію, що підтверджувалося даними динамічного аналізу клініко-психопатологічних порушень за шкалою PANSS. Рівень виразності позитивних симптомів в основній групі знизився на 69,3 \%, в контрольній - на 41,1\%; негативних симптомів в основній групі знизився на 61,1 \%, в контрольній - на 49,8 \%; загально-психопатологічних симптомів в основній групі знизився на 60,8 \%, у контрольній - на 39,7 \%, відповідно; загального балу за шкалою PANSS в основній групі знизився на 65,1%, в контрольній на $42,9 \%$.

У ході роботи встановлено, що на тлі комплексної терапії з використанням арт-терапії суттєво покращився рівень соціального функціонування хворих, а саме загальної поведінкової дисфункції в основній групі - на 75,3\%; у контрольній - на $52,1 \%$; дисфункція при виконанні соціальних ролей - на 61,5 \% в основній і 31,9 \% контрольній відповідно; порушення функціонування пацієнтів у лікарні - в основній групі на 86,4%; у контрольній на 69,4\%; дисфункція модифікуючих чинників у хворих - на 91,1 \% в основній та 59,8 \% контрольній групах.

Таким чином, використання арт-терапії, поряд 3 фармакотерапією пацієнтів 3 шизофренією надає позитивний вплив на відчуття психологічного благополуччя, посилення почуття причетності і особистісної реалізованості, поліпшення міжособистісних відносин, відчуття підтримки від близьких і соціуму, що, в свою чергу, відбивається на загальному сприйнятті якості життя.

Отримані дані, щодо ефективності арт-терапії у терапії та психосоціальній реабілітації психічно хворих корелюють 3 даними вітчизняних дослідників [10] підтверджують дані про позитивний вплив арт-терапії психосоціальну реінтеграцію хворих на шизофренію [11] та свідчать про необхідність подальшої розробки та впровадження арт-терапевтичних заходів у систему психосоціальної реабілітації психічнохворих.

\section{7. Висновки}

1. Використання арт-терапії хворих на шизофренію поряд з фармакотерапією надає позитив- 
ний вплив на розвиток і підтримку творчих навичок пацієнтів; від реагування їх почуттів, розвиток комунікативних навичок, соціальну реінтеграцію хворих.

2. Арт-терапія заснована на розроблених принципах, для хворих на шизофренію характеризується вищою ефективністю порівняно з методами, які використовувалися традиційно.

3. Катамнестичне дослідження, яке здійснювалося протягом року, свідчило про стійкість досягнутого ефекту у пацієнтів, які продовжили участь в арт-терапії на амбулаторному етапі лікування.

\section{Література}

1. Кожина, А. М. Опыт применения препарата Солерон в терапии шизофрении [Текст] / А. М. Кожина, Л. М. Гайчук // Український вісник психоневрології. - 2010. - Т. 18, № 4 (65). - С. 116-117.

2. Волошин, П. В. Стратегія охорони психічного здоров'я населення України: сучасні можливості та перешкоди [Текст] / П. В. Волошин, Н. О. Марута // Український вісник психоневрології. - 2015. - Т. 23, № 1(82). - С. 5-11.

3. Марута, Н. А. Стан надання та перспективи розвітку психіатричної допомоги в Україні [Текст] / Н. А. Марута // Архів психіатрії. - 2011. - Т. 17, № 3 (66). - С. 5-9.

4. Підкоритов, В. С. Психіатрія в Україні - минуле, теперішнє, майбутнє [Текст] / В. С. Підкоритов // Вісник психіатрії та психофармакотерапії. - 2008. - № 2 (14). - С. 29-32.

5. Діхтяр, В. О. Рівень соціального функціонування та якості життя як основа психотерапії хворих на параноїдну шизофренію [Текст] / В. О. Діхтяр // Український вісник психоневрології. - 2009. - Т. 17, № 3 (60). - С. $35-44$.

6. Гуменюк, Л. Н. Арт-терапия в системе комплексной психосоциальной реабилитации больных шизофренией в условиях принудительного лечения [Текст] / Л. Н. Гуменюк, Е. А. Михайлова // Таврический медико-биологический вестник. 2010. - № 4. - С. 37-40.

7. Стан психічного здоров'я населення та психіатричної допомоги в Україні (інформаційно-аналітичний огляд за 2001-2010 р.р.) [Текст]. - Київ-Харків, 2011. - 173 с.

8. Пшук, Н. Г. Предиктори формування процесу психосоціальної реабілітації психічнохворих [Текст] / Н. Г. Пшук // Український вісник психоневрології. - 2010. - Т. 18, № 3 (64). - С. 145.

9. Korostiy, V. Art-therapy in Complex Treatment of Major Depressive Disorder [Text] / V. Korostiy, S. Hmain // European Psychiatry. - 2015. - Vol. 30. - P. 1324. doi: 10.1016/s0924-9338(15)31033-6

10. Hmain, S. Effectiveness of art therapy in complex treatment of patients with depressive recurrent disorder [Text] / S. Hmain // Deutsche Gesellschaft für Psychiatrie und Psychotherapie, Psychosomatik und Nervenheilkunde Kongress. - Berlin, 2015. - P. 12-004.

11. Колядко, С. П. Особливості використання арт-терапії в лікуванні хворих на параноїдну шизофренію [Текст] / С. П. Колядко, Г. Ю. Каленська // Український вісник психоневрології. - 2017. - Т. 25, № 1(90). - С. 51-55.

Рекомендовано до публікаиії д-р мед. наук, професор Кожина Г. М. Дата надходження рукопису 19.05.2017

Кришталь Олександр Олексійович, лікар психіатр, Харківська обласна клінічна психіатрична лікарня № 3, вул. Академіка Павлова, 46, м. Харків, Україна, 61001

E-mail: krishtalmail@ukr.net 